\title{
Epilens membrane simulating cataract in children with uveitis: a report of three cases
}

\section{Membrana epicristaliniana simulando catarata em crianças com uveíte: relato de três casos}

\author{
Roberta Paiva ${ }^{1}$, Heloisa Nascimento ${ }^{2}$, Gustavo Salomão ${ }^{3}$, Lincoln Freitas ${ }^{2}$, Cristina Muccioli², Rubens Belfort Jr. ${ }^{2}$
}

\begin{abstract}
Here we present the cases of three female children, of whom two were aged 6 years and one was aged 11 years. Two of the three children had bilateral uveitis and suspected cataract and Vogt-Koyanagi-Harada (VKH) disease. The third one had uveitis and suspected cataract in one eye and sympathetic ophthalmia (SO), and had undergone penetrating keratoplasty in the fellow eye following a trauma. After controlling the inflammation, we planned to perform phacoemulsification without intraocular lens implantation. However, intraoperatively, after removing the epilens membranes, the lenses appeared clear, and therefore phacoemulsification was not performed. During follow-up, the patients did not develop cataract, and visual acuity levels ranged from 20/30 to 20/100. Fundoscopy revealed VKH disease and SO. Ophthalmologists should not always assume that patients with uveitis have cataract; a transparent lens may exist behind the epilens membrane, allowing a less aggressive therapeutic approach.
\end{abstract}

Keywords: Epilens membrane Uveitis; Cataract; Phacoemulsification; Child; Sympathetic ophthalmia

\section{RESUMO}

Apresentamos os casos de três meninas (duas de seis anos e uma de onze anos), com uveíte bilateral e suspeita de catarata em ambos os olhos e doença de Vogt-Koyanagi-Harada (VKH) em dois casos. No terceiro caso, oftalmia simpática e suspeita de catarata em um olho e trauma com ceratoplastia penetrante no outro olho. Após controle da inflamação, indicou-se facoemulsificação sem LIO. No per-operatório, após retirada da membrana epicristaliniana, a transparência do cristalino foi percebida, não sendo realizada a facoemulsificação. No período de acompanhamento as pacientes não desenvolveram catarata e a acuidade visual variou de 20/30 a 20/100. O exame de fundoscopia reforçou o diagnóstico de VKHe oftalmia simpática. Portanto, é muito importante que o oftalmologista esteja sempre atento quando se deparar com um caso de uveíte com suspeita de catarata, porque, por trás da membrana epicristaliniana pode existir um cristalino transparente, o que leva a uma conduta terapêutica menos agressiva.

Descritores: Membrana epicristaliniana; Uveíte; Catarata; Facoemulsificação; Crianças; Oftalmia simpática

\section{INTRODUCTION}

Cataract is a common complication of uveitis, and may result from chronic intraocular inflammation because of the use of corticosteroids. Cataracts are difficult to manage, particularly in children; therefore, choice of surgery should be based on the assessment of quality of vision; preoperative control of inflammation; and intraoperative issues such as poor visibility due to band keratopathy, myosis, synechiae, pupillary membranes, and bleeding (1). Postoperative follow-up may also be challenging, and the frequency of complications may be higher than usual(1-6).

However, diagnostic techniques and medical and surgical treatments have greatly improved, increasing surgical indications. Furthermore, cataracts in children may be amblyogenic, which does not facilitate diagnosis and treatment of posterior segment complications ${ }^{(1-6)}$.

\section{CASE REPORTS}

We report the cases of three female children, two of whom were aged 6 years and one was aged 11 years. All girls reported bilateral low visual acuity, ranging from the ability to count fingers at a distance of $3 \mathrm{~m}$ to light perception; two of the girls were diagnosed with bilateral chronic diffuse uveitis and Vogt-Koyanagi-Harada (VKH) disease and the third girl was diagnosed with sympathetic ophthalmia (SO).

Biomicroscopy showed band keratopathy, granulomatous keratic precipitates, posterior synechiae, and opaque pupillary membranes, which bilaterally obstructed the lens evaluation in two girls, and also in one eye of the third girl who had undergone penetrating keratoplasty with graft failure in the fellow eye.

Intraocular pressure levels were within normal limits. Fundus evaluation was impossible because of media opacity. Ultrasound revealed that the posterior segments were unchanged. After controlling inflammation with topical and systemic steroids, several experienced ophthalmologists recommended phacoemulsification without intraocular lens implantation in the left eye of each patient.

Intraoperatively, after lysing the posterior synechiae and excising the epilens membrane, the crystalline lenses were observed to be transparent, and the red reflex was present; therefore, phacoemulsification was not performed. Fundoscopy, which was possible postoperatively, revealed $\mathrm{VKH}$ disease and SO. The three patients recovered well postoperatively, with mild inflammatory reactions, and achieved best-corrected visual acuities ranging from 20/30 to 20/100. The three patients did not develop cataract during the postoperative period, which ranged from 1 to 7 years (Figures 1, 2, and 3).

\section{DISCUSSION}

Here we report three girls with uveitis and suspected cataract, whose lenses appeared transparent upon membranectomy. Phacoemulsification was aborted in all three cases.
Submitted for publication: August 19, 2014 Accepted for publication: January 19, 2015

Clóvis Paiva Eye Institute, Recife, PE, Brazil.

Department of Ophthalmology, Escola Paulista de Medicina (EPM), Universidade Federal de São Paulo (UNIFESP), São Paulo, SP, Brazil.

${ }^{3}$ Department of Ophthalmology, Faculdade de Medicina do ABC, São Paulo, SP, Brazil.
Funding: No specific financial support was available for this study.

Disclosure of potential conflicts of interest: None of the authors have any potential conflict of interest to disclose.

Corresponding author: Roberta Paiva. Rua Dom Bosco, 855 - Recife, PE - 50070-070 - Brazil E-mail: betapaiva@hotmail.com 

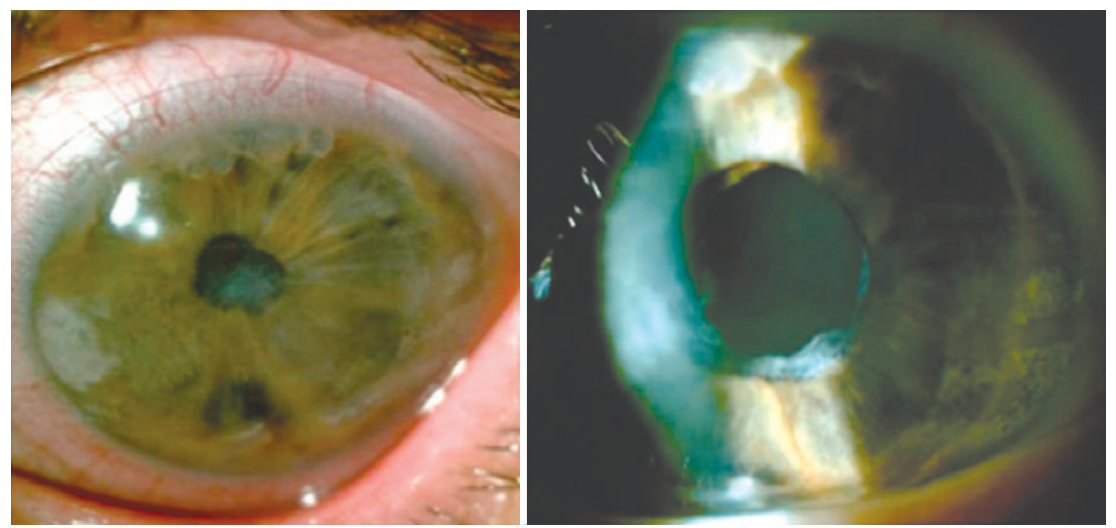

Figure 1. Before and after epilens membrane removal (Caso 1).
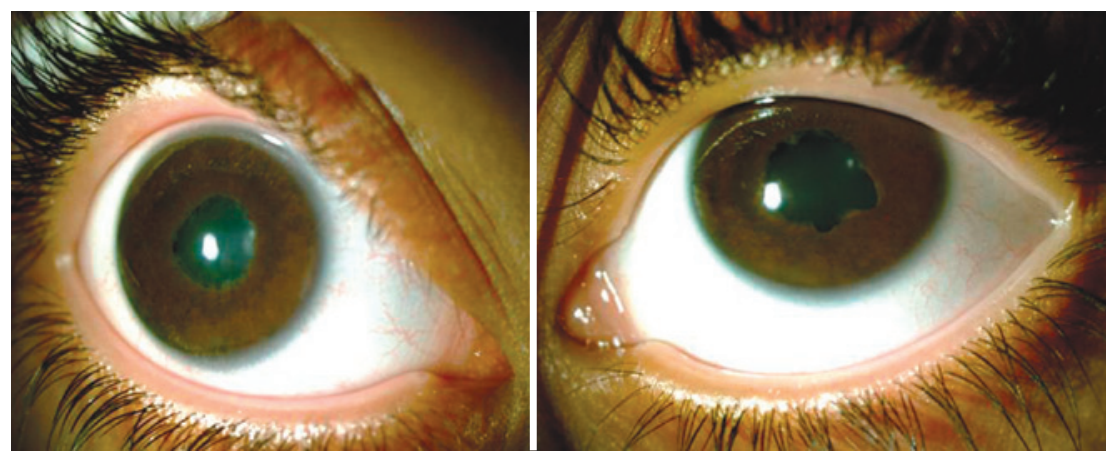

Figure 2. Before and after epilens membrane removal (Caso 2).
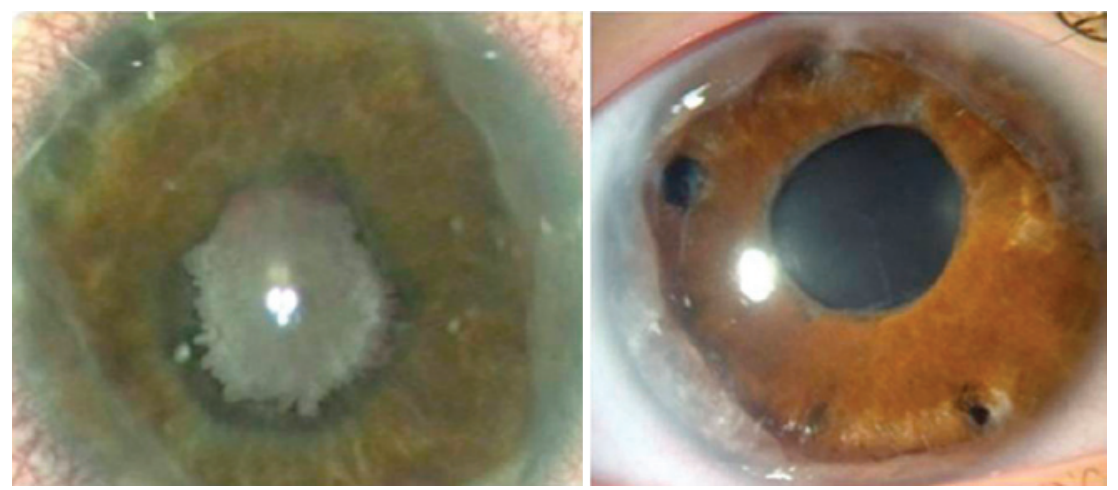

Figure 3. Before and after epilens membrane removal (Caso 3).

The three patients had surgical indications for phacoemulsification, and despite the assumption of cataract, the girls actually had epilens membranes and transparent lenses.

If the patients had not been carefully evaluated intraoperatively with delicate removal of the inflamed epilens membranes, the crystalline lenses could have been removed, inadvertently risking future vision and increasing the possibility of the development of secondary glaucoma and other diseases ${ }^{(5,6)}$.

It is important to emphasize the risk of rupture of the anterior capsule during the release of the prepupillary membrane and synechiolysis. Therefore, surgeons need to have sufficient skill and practice to perform these very delicate maneuvers to avoid complications.

Differential diagnosis of leukocoria in children with uveitis should include epilens membranes. Patients who develop uveitis with a pupillary membrane as a complication should be carefully evaluated. Intraoperatively, if the lens is found to be transparent, a less aggressive therapy should be instituted. Ophthalmic surgeons should consider removal of epilens membranes as a surgical option.

\section{REFERENCES}

1. Baheti U, Siddique SS, Foster CS. Cataract surgery in patients with history of uveitis. Saudi J Ophthalmol. 2012; 26(1):55-60.

2. Foster CS, Rashid S. Management of coincident cataract and uveitis. Curr Opin Ophthalmol. 2003;14(1):1-6

3. Agrawal R, Murthy S, Ganesh SK, Phaik CS, Sangwan V, Biswas J. Cataract surgery in uveitis. Int J Inflamm. 2012;2012:548453.

4. Murthy SI, Pappuru RR, Latha KM, Kamat S, Sangwan VS. Surgical management in patient with uveitis. Indian J Ophthalmol. 2013;61(6):284-90.

5. Elgohary MA, McCluskey PJ, Towler HM, Okhravi N, Singh RP, Obikpo R, Lightman SS. Outcome of phacoemulsification in patients with uveitis. Br J Ophthalmol. 2007; 91(7):916-21.

6. Wentworth BA, Freitas-Neto CA, Foster CS. Management of pediatric uveitis. F 1000 Prime Rep. 2014;6:41. 